\title{
Actor-network Theory and cartography of controversies in Information Science ${ }^{1}$
}

\section{A Teoria Ator-rede e a cartografia de controvésias na Ciência da Informação}

\author{
Ramon Fernandes LOURENÇO² \\ Maria Inês TOMAÉL²
}

\begin{abstract}
The present study aims to discuss the interactions between the Actor-network Theory and the Cartography of Controversies method in Information Science research. A literature review was conducted on books, scholarly articles, and any other sources addressing the Theory-Actor Network and Cartography of Controversies. The understanding of the theoretical assumptions that guide the Network-Actor Theory allows examining important aspects to Information Science research, seeking to identify the relationships between information, people, and technological equipment in the structure of information flows that create intricate information sharing networks. This interaction between the Actor-network theory and Information Science highlights the role of the research method Cartography of Controversies as an approach that results from the use of the Actor-network theory to investigate the creation of sociotechnical networks.
\end{abstract}

Keywords: Actor-network theory. Cartography of controversies. Information science.

\section{Resumo}

Este artigo tem por objetivo discutir as aproximações entre a Teoria Ator-Rede e a metodologia Cartografia de Controvérsias para as pesquisas na área da Ciência da Informação. Para a elaboração deste estudo foi utilizada a metodologia de pesquisa bibliográfica, com o propósito de analisar os estudos e artigos produzidos que utilizam a Teoria Ator-Rede e a Cartografia de Controvérsias. Ao entender os pressupostos teóricos que guiam a Teoria, é possível verificar pontos importantes para as pesquisas na Ciência da Informação, buscando identificar as relações entre a informação, as pessoas e os equipamentos tecnológicos, na conformação de fluxos de informação que criam intrincadas redes de compartilhamento. Nessa aproximação entre Teoria Ator-Rede e Ciência da Informação, destaca-se o papel da metodologia de pesquisa Cartografia de Controvérsias como um método fruto da aplicação dessa Teoria para o estudo das formações das redes sociotécnicas.

Palavras-chave: Teoria Ator-Rede. Cartografia de controvérsias. Ciência da Informação.

\section{Introduction}

Information dynamics today occurs at a speed faster than ever before. There is now the possibility of visualizing and keeping track of the changes being made in different places around the world from your workplace,

\footnotetext{
1 Article based on the master's thesis of R.F. LOURENÇO, entittled "Cartografia de controvérsias: uma análise da mediação informacional no processo de organização em rede das ocupações das escolas de São Paulo". Universidade Estadual de Londrina, 2016.

2 Universidade Estadual de Londrina, Departamento de Ciência da Informação, Programa de Pós-Graduação em Ciência da Informação. Rod. Celso Garcia Cid, Pr 445, Km 380, Campus Universitário, 86057-970, Londrina, PR, Brasil. Correspondência para/Correspondence to: R.F. LOURENÇO. E-mail: <uel.ramon@gmail.com>.

Received on July 21, 2016, final version resubmitted on May 16, 2017 and approved on June 23, 2017.

Como citar este artigo/How to cite this article

Lourenço, R. F.; Tomaél, M. I. Actor-network Theory and cartography of controversies in Information Science. Transinformação, v. 30, n. 1, p. 121-140, 2018. https://doi.org/10.1590/2318-08892018000100010
} 
your home, or even at the bus stop, using mobile technologies. Information is obtained almost anytime, anywhere. This new information dynamics can cause major changes in the ways in which social relations are constructed and understood, generating new behaviors and new points of view in this increasingly fluid and instantaneous world.

In order to understand how network creation occurs in this new world, resulting from the hybridity between the real and the virtual, one needs to rethink society and social concepts revisiting the association processes and creation of links and searching for new agents that can influence this process. This is the issue addressed in the Actor-Network Theory formulated by Michel Callon, Bruno Latour, and John Law, whose proposal is to rethink the "social" based on its associations, criticizing the traditional conceptions of sociology.

It is by deconstructing the idea that social and society are well-established, and complete categories that impose structure on any association between individuals that the Actor-Network Theory (ANT) takes into account the current dynamics of this connected world, in which changes have occurred at an increasingly faster rate, and social relationships have become more fleeting and fluid. Thus, the provisional process of associations and dissociations define the "social", and society is the consequence of these associations and not their cause.

Aiming at carrying out an effective study based on the perspective of the Actor-Network Theory, the Cartography of Controversies method was developed, which is an applied version of the theory itself (Venturini, 2010). In order to analyze social phenomena that are subject to a process of constant transformation, this method seeks to retrace the steps taken by human- and non-human agents using the information recorded in several different formats to ensure that all parties involved in the controversy are present in the analysis.

Due to this new perspective proposed by the ANT, the objective of the this study is to present and discuss the contributions of this theory to Information Science research, highlighting the role of the research approach Cartography of Controversies as the method for the study of the creation of sociotechnical networks. Therefore, some definitions of this method and its main steps and tools are provided, contributing to future studies in the Information Science field.

\section{Methodological procedures}

The present study was carried out based on a literature review whose focus was to analyze the Brazilian scientific production addressing the cartography of controversies and the actor-network theory to obtain a structured content that emphasizes the similarities between these approaches and information science research.

This study started based on a search of studies carried out in the country using the ANT or the Cartography of Controversies that are available in the Banco de Dados de Teses e Dissertações (BDTD, Thesis and Dissertations Database) of the Instituto Brasileiro de Informação em Ciência e Tecnologia (IBICT, Brazilian Institute of Information on Science and Technology). The search identified 121 studies addressing these topics in graduate courses in different areas, such as administration, communication, health, language and literature, sociology, anthropology, environmental engineering, and multidisciplinary areas. The small number of studies published in these areas indicates that greater efforts are needed in order to make this theory and method known since they are relatively new and there has been little research published in Portuguese language addressing them. Only three theses and dissertations in information science were identified.

In addition to this database, Google Scholar was also used to search for electronic copies of studies published between 2015 and 2016 on these two topics to identify how ANT and CC were addressed. In the analyzed articles, there was a brief description of the method and theory, and only one of their specific elements was more discussed in detail, failing to contribute to a more comprehensive account of the processes and tools available.

The primary authors of all of those scientific productions were identified and served as basis for the theoretical framework of the present study. 


\section{Actor-network theory: foundations of a new cartography}

The actor-network theory was created in response to constant changes in a world where technology and science have been more deeply embedded in people's lives, and its proposal is to establish new ways of analyzing phenomena that are already known. Therefore, the ANT is based on two key principles: the criticism of the traditional conceptions of society and "social" arising from sociology and the recognition of the agency potential of non-human elements that directly influence the construction of the "social".

The first central point of the ANT is questioning the traditional sociology conceptions of what is conventionally called "social" and "society". According to the ANT, these two terms describe something in motion, an unstructured flow in constant transformation, highlighting what Latour's remarks on the traditional conception, who stated that "the problem with any ostentatious definition of 'social' is that no extra effort seems necessary to preserve the existence of groups [...]" (Latour, 2012, p.60).

Understanding the concepts of society and "social"as well-established, well-founded, and steady phenomena, means disregarding the movements and flows that take place to maintain existing bonds. This is the point that Latour draws attention to; it regards effort, work, the very action (agency) that creates and maintains social bonds. Without this effort devoted to create and recreate bonds, there is no "social", and this is the reason why the "social" is in constant transformation; it is not something considered as concluded or definitive.

For ANT, the term "social"'" [...] does not designate a domain of reality or some particular item, but rather is the name of a movement, a displacement, a transformation, a translation, an enrollment" (Latour, 2012, p.99). The social world is composed of networks of interactions, in which each new contact or new interaction is transformed and recreated. Therefore, this theory focuses on the study of the movements that characterize social phenomena based on observations of the agents involved, their role in the network, and the factors influencing these movements.

This focus allows the analysis of the "social" real dynamics since it takes into account that conceptual structures, such as culture and economic and social influence to provide predefinitions (preconceptions), which are used to capture an image or describe a social phenomenon, which will reveal very little about it. The reason is that this will hardly consider other factors that directly influence the case analyzed and are included in universes that are very close to those of the agents involved. In other words, in order to analyze a social phenomenon, the scholar has to experience it. Thus, ANT scientists argue that fluidity is the most important feature of the "social": "It is only a movement that can be seized indirectly when there is a slight change in one older association mutating into a slightly newer or different one. Far from a stable and sure thing, it is no more than an occasional spark generated by the shift, the shock, the slight displacement of other non-social phenomena" (Latour, 2005, p.36).

Therefore, the search of actor-network theory is focused on these movements, which are sometimes crated by other non-social phenomena since they are the ones that build up and establish a network and its connections. This is the reason that in order to "reassemble the social" (Latour, 2012), it is necessary to retake the actors' steps, retracing the paths followed by the movements, tying and untying connections, which will reveal a brief view of the network.

Another key issue raised in the ANT is that "agency" can be attributed to non-human elements in a network, not in a social network but in a sociotechnical network. This conception allows us to recognize how technical artifacts can influence human actions and relationships. This is very important in the current context of great technological advances, in which technological devices interact with people and with other devices around them.

The understanding of "social" based on its connections and the movement involved in the bond between the agents implies the need to review who these agents are in the current context, in which technological devices are attributed with agency and direct action in highly diverse human environments. This is a very important advancement due to ANT, i.e., rethinking the role of non-human elements in association processes recognizing 
their ability to act when interacting with each other and with humans. Medeiros clarifies some points regarding the role of non-human agents in the composition of a network.

To view objects as part of a network means to conceive their existence as essential for the formation of the network. Such inclusion has been discussed and reported in scientific research, in which they are no longer relegated, but rather they are considered as a key element in many conceptions of what takes place in an environment. Performing an action implies the use of other entity (s), i.e., it is not possible to perform an action alone. The action includes different types of objects that form a network of the action performed, that is, a collective sociotechnical group (Medeiros, 2015, p.73).

Analyzing everyday actions facilitates understanding the ANT proposition regarding the role of non-human agents, especially now when technology is gaining more prominence. Nowadays, people are surrounded by technological devices to perform many actions. In order to stay connected with friends, people use smartphones and real-time chat applications. Computers and video-conferencing software are used to live stream business meetings, and car navigation systems are used to get planned direction for the voyage or locate places on a map.

These are examples of how non-human agents compose an intricate network in which they are essential, i.e., if they were removed, the network would be unfeasible. The network composed of humans and non-humans is called the sociotechnical network (Latour, 2012) because it recognizes the equal importance of these agents, regardless of their nature. Thus, the Actor-network theory offers a new conception by recognizing the importance of the new technologies in the construction of sociotechnical networks.

In order to recognize the importance of non-human elements in the formation of these sociotechnical networks, the ANT no longer uses the term actor to identify the agent in the network. It proposes the use of the term actant, as reported by Latour (2012). According to the ANT, the nature and characteristics of the actants do not assert their importance in the network. Their importance or role in the network is indicated by the actions performed by the actants and their potential to transform the network.

This defines the symmetry principle, i.e., when analyzing a network, the scholar should not assert primacy of human actants over non-humans, and vice versa. This principle shows that the presence of objects, combined with the human elements involved, is essential in the constitution of a network.

This means major steps towards putting aside the duality imposed by the division between the social world and the world composed of things, understanding that an action includes different types of agents. Moreover, by retracing the steps of an action, without a priori restriction of the participating entities, the scholar will be able to have a brief view of the complex network, visualizing the entire phenomenon in its totality and heterogeneity.

Based on this understanding of social phenomena, the actor-network theory is an important tool in the analysis of the current rapid transformation rates. By focusing on the continuous processes of tying and untying connections, in the movements of an increasingly fluid world, the ANT allows an analysis of the phenomena from a perspective that disregards the boundary between the social world and the world of objects, asserting the importance of the action performed by the network actors in their diverse forms, like a fuel that keeps these flows constantly moving.

In order to further understand this theory as a foundation for the cartography of controversies, it is necessary to deepen the knowledge of some concepts regarding how the actants act within a network, revealing the connections with information sharing processes and with Information Science studies.

\section{The actants and their role in the sociotechnical network}

By making an effort to understand that the network is composed of people, objects, documents, discourses, ideologies, and other non-human elements, the scholar recognizes the heterogeneity related to the phenomenon 
being analyzed, broadening the understanding of the role of each actant in this process. As previously mentioned, the actions of these actants are the links in the network, establishing the tying and untying connection processes when there are no more actions. Therefore, the movement of the actants is the key to understand the social dynamics, and thus the focus should now be given on the analysis of how they act in the network, which also helps visualizing how the information sharing processes, object of study in Information Science, can be addressed in the ANT.

According to the actor-network theory, actants play two different roles in a network: mediators and intermediaries. However, it is important to mention that these two concepts are fundamental to understand their movement in the network since they describe the "constant uncertainty over the intimate nature of entities - are they behaving as intermediaries or mediators?" (Latour, 2005, p.39). In other words, all actants in the network will exhibit one of these behaviors, revealing the network paths.

The intermediary is responsible for transporting meaning or force without transforming it, i.e., "defining its inputs is enough to define its outputs" (Latour, 2005, p.39) is the standard behavior pattern of this entity in the network. In the cartography of the sociotechnical network, the intermediary can be counted as just one if its removal from the network causes instability. If its removal does not have any effect on the network, its presence is not accounted for.

On the other hand, mediators are responsible for transformations, and describing their characteristics and their effects on the network is a complex task for scholars. In the words of Latour, mediators.

[...] cannot be counted as just one; they might count for one, for nothing, for several, or for infinity. Their input is never a good predictor of their output; their specificity has to be taken into account every time. Mediators transform, translate, distort, and modify the meaning or the elements they are supposed to carry (Latour, 2005, p.39).

In this process of identifying the mediators and their effects, it is important to concentrate attention on their characteristics as actor-network since, in certain actions, the same mediator can counted as one or several in the network. In practice, this refers to multiple effects that can be produced by the same mediator influencing the network in very different ways. This is why Latour demonstrates the need to take into account the specificity of this actant in each new action and each new effect related to it.

The potential for transformation characterizes the difference the between intermediary and mediator, i.e., the ability to transform or to translate. Translation is the preferred term by ANT, and it is the heart of the process of transformation brought about by the mediator. Since their input is never a good predictor of their output, a translation process takes place.

Analyzing the concept of translation proposed by the ANT sociologists, Pedro (2008) argues that it is a philosophical concept that describes the process of connecting, tracing paths or communicating with a strong inventive tendency and a mixture of diverse elements. According to this author, translation does not refer only to discursive change but also to "a movement, a deviation of route, a mediation or invention of a non-existent relationship, which somehow modifies the actors involved affecting the network" (Pedro, 2008, p.6).

Therefore, translation is a process that leads to a series of effects, completely transforming the network. It occurs as the actant interacts with the action/information it receives, transforming it according to its own characteristics, interests, or beliefs, providing the network with something different from what was received. This process can also be understood as "the interpretation given by the fact-builders of their interests and that of the people they enroll" (Latour, 1987, p. 108), noting that such an action is not performed by human- and non-human elements.

Law (1992) highlights the understanding of translation as a central process for the understanding of the ANT. 
So 'translation' is a verb which implies transformation and the possibility of equivalence, the possibility that one thing (for example an actor) may stand for another (for instance a network). This, then is the core of the actornetwork approach: a concern with how actors and organisations mobilise, juxtapose and hold together the bits and pieces out of which they are composed (Law, 1992, p.386).

During the analysis of mediations and translations, the scholar will encounter the difficult task of retracing the path of the movements of the tying and untying connections that transform the network. According to Latour, "If you mention an agency, you have to provide the account of its action, and to so you need to make more or less explicit which trials have produced which observable traces" (Latour, 2005, p.53).

The traces and evidence of the actions performed are the inscriptions that is, the materialization of the element that symbolizes the action itself. To search for traces of actions, the scholar has to analyze a great diversity of documents seeking, in the most diversified media support, elements that prove the accomplishment, i.e., evidence that that the action was performed, to help with the challenge of describing it accurately. In the relationship between inscription and action as a network link, Praude points out that "association is defined based on the scripts (codes, maps, rules, standards, and laws) implemented in different types of resources so that the action is always fruit of hybridity and of the production of results" (Praude, 2015, p.38).

Thus, the interest of the actor-network theory in the actions performed by the actants and their effects on the network is confirmed since "An invisible agency that makes no difference, produces no transformation, leaves no trace, and enters no account is not an agency" (Latour, 2005, p.53). Therefore, the scholar should follow the actions that produce transformations and leave traces. Retracing the actants'steps is one way to obtain cartographic representation of the network, and through the analysis of their inscriptions, it is possible to describe the dynamics which is the "social". This is the major interaction between the Actor-Network Theory Cartography of Controversies method since both share the same premise: "The presence of the social has to be demonstrated each time anew; it can never be simply postulated" (Latour, 2005, p.53).

\section{Cartography of controversies: just follow the actors themselves}

Accordingly, the Cartography of Controversies has been considered as a method based on the principles of the Actor-Network Theory, understanding social phenomena as something under constant transformation and recognizing the symmetry between human- and non-human agents in the formation of sociotechnical networks.

In the Information Science (IS) field, this method is recognized as having great potential to be used in studies focused on understanding the role and effects of information within a network, especially those related to digital and technological environment. Since most common objects of research, although not the only ones, in the cartography of controversies are related to science and technology, their connection with the IS is even more evident. Therefore, the cartography of controversies allows us to deal with this scenario, in which there is an increasing heterogeneity of informational sources, providing an overview of a specific event by tracing the path of the actants during the development of the controversy.

\section{The Context of Cartography of Controversies}

The Cartography of Controversies and the Actor-Network Theory are commonly used in the interdisciplinary studies of Science, Technology, and Society (STS), a movement that began in the 1970s resulting from research in philosophy and sociology of science, which aims at establishing the relationship between the social context and the advancement of science and technology (Pinheiro; Silveira; Bazzo, 2007). This movement emerged in response to the rapid technological changes produced in the following years, stirring up concerns about the effects of these 
technologies on society. Concerns about the impacts and limitations of health technologies in society, the effects of mass media, and the social and environmental impacts of new food production methods are examples of issues that are addressed in the STS field are related to a critical evaluation of scientific and technological developments.

Today, more than forty years after the beginning of this movement, it is becoming even more evident how the effects of rapid scientific and technological advances have profoundly transformed the world. This directly impacts the foundations of society, changing the way individuals interact with one other, their attitudes and behavior patterns, and the relationship between society, space and time. The different types of technologies that have become part of individuals' lives have changed not only the aspects external to them, such as means of transport, housing, and communication, but their view of the world and their cognitive skills are also different from those of past decades, emphasizing the differences between the generations. Pedro (2008) highlights some of these changes addressing the STS challenge of investigating this issue based on the network concept bias, pointing out to the potential of this interdisciplinary dialogue.

[...] the changes caused by science and technology, whose increasing presence in the most different spheres of knowledge and life has brought new forms of cognition, interaction, social action, political activism, and knowledge generation and diffusion. According to the network conception, science, technology, and society are connected to each other, establishing complex and heterogeneous relationships, calling into question the determinisms to which research is often subjected (Pedro, 2008, p.1).

This interdisciplinary alignment allowed advances in the search for solutions to increasingly complex problems, enabling dialogue between disciplines that used to be isolated, such as philosophy, sociology, communication, information science, engineering, mathematics, and medicine, in order to nullify disciplinary determinisms and simplistic conceptions of increasingly complex problems.

In this context involving the recognition of the complexity of contemporary problems, in which one can also recognize the multiple dimensions of current issues, linear methods that oversimplify phenomena can no longer explain the elaborate set of processes that lead to the current circumstances and events. The Cartography of Controversies approach was developed due to questionings arising from reflections on science, technology, and society, and it has been considered as the method that aims to analyze techno-scientific questions, trying to understand the role of human- and non-human agents within a sociotechnical network.

Based on the actor-network theory premises, this approach focuses on the analysis and description of the creation, development, and end of controversies. Controversies are the object of analysis because they are a phenomenon that allows us to observe the dynamics of tying and untying connections in sociotechnical networks (Venturini, 2010), based on the role played by the actants in their produced discourses. The rise of the internet and the means of communication has contributed to the advances of this method (Marres, 2015, p.658) offering new possibilities for its evolution since the internet enables the access to several different points of view about the same problem, and every interaction and every new content generated leaves a trace.

The method introduced by Bruno Latour has led to a joint research initiative that gathers scholars in science, technology, and society across Europe and the United States called MACOSPOL (Mapping Controversies on Science for Politics) <http://mappingcontroversies.net>. Its goals devise a collaborative platform to disseminate tools and techniques to map out scientific and technical controversies.

\section{Definitions of Cartography of Controversies}

The increase in the use of this approach is due to the evolution of the Web itself since the production of contents and their different points of view compose a plentiful field in which controversies can be mapped. However, due to its increased use, it is also necessary to provide a proper understanding of the method, its definitions, steps, 
and tools, by searching relevant available literature on this subject. According to Pedro (2008, p.11), Cartography of Controversies "is a research approach that appears to go against the traditional scientific research because it is not focused on previously well-established knowledge but rather on situations involving uncertainty, risk, and conflict", reinforcing the need for a proper conceptualization about this method so that it can be adequately employed and improved over time.

The Cartography of Controversies emerged as an applied version of the Actor-network Theory, and it is widely used by students and scholars who want to describe the process of associations involved in the creation of the "social". Latour describes the essence of this method in an interesting way by saying, "just look at controversies and tell what you see" (Venturini, 2010, p.259). This is truly the central characteristic of this method, but the scholar who intends to use it should not take into account only the superficial reading of this minimalist description, which, however, includes many important meanings for the understanding of cartography of controversies.

After the first reading of this sentence - "just look at controversies and tell what you see" - by Latour (Venturini, 2010, p.259), one can easily see the challenges in employing this method, as highlighted by Venturini, who describes the three consequences that are implied in the term "just". As the first consequence of "just", the author emphasizes that scholars who wants to use the method should be aware that they do not have to use a single theory or method; they are not forbidden to employ other tools to help the analysis of their controversy. This means that the Cartography of Controversies is a method developed for dealing with the unceasing work of tying and untying connections that compose the "social", and in order to deal with something so complex, the method must be open and, to a certain extent, have the same dynamics of the phenomena being analyzed. Thus, the scholars using the method should bear in mind that depending on their object of study, they can and should use other methods and tools to support the construction of a map that can represent the complex movement of controversies.

The second consequence of "just" is another issue regarding the use of the method is the need to investigate different points of view as much as possible because "the more numerous and partial are the perspectives from which a phenomenon is considered, the more objective and impartial will be its observation" (Venturini, 2010, p.260). This is undoubtedly one of the most important principles of this method and the reason demanding great effort on the part of the scholar. Constructing detailed and comprehensive maps that explain the dynamics of the controversies based on the actants' voices does not mean to pretend to be impartial towards the object being investigated but to ensure that several voices are present in the description of the controversy, a broad range of perspectives. Only then will it be possible to obtain a clear picture of the social phenomenon being analyzed.

Accordingly, regarding bias, the third consequence concerns the scholar's attitude, which differs from other methods. In the cartography of controversies, the scholar must consider that the actors are the specialists since they are the ones who are immersed in the analyzed phenomenon. In Venturini's words (2010, p.260), "the cartography of controversies entails the idea that participants to social phenomena may be as informed as investigators". This attitude enables scholars to learn from the actors how to observe collective life and ensure richer accounts in terms of points of view.

These three consequences provide a clear idea of the complex task of describing tying and untying connections using the Cartography of Controversies, demonstrating its lengthy and highly analytical process. Since this is a method with so many different aspects, its definitions and explanations are, at first, somewhat difficult for those interested in using it.

In order to define this method in a simpler and more objective way, some authors have provided their own definitions, for exemple, Marres (2015, p.657), who describes it as a"digital method involves the use of computational techniques to detect, analyze, and visualize public contestation over topical affairs". Similarly, Pereira and Boechat 
(2014, p.560) state that Cartography of Controversies is "[...] a set of methods to visually represent and analyze topics based on traces left by actors in digital networks using information and communication technology tools".

These two definitions contribute to a good understanding of the method in a simplified way, addressing important points such as the connection with the digital environment, its main characteristics, and the public issues that are the controversies themselves. As previously described, the advancement of digital technologies has boosted the development of methods of social analysis, especially those that are based on the notion of networks, such as the Social Network Analysis and the Actor-Network Theory, since it is now possible to review the traces left by them in the digital environment during their interactions with tools, contents, and people on the Web. These traces are analyzed and defined from the perspective of the actor-network theory by Bruno (2012) as the "footprints we leave in the distributed communication networks, especially in the Internet, where every action leaves a potentially traceable path, constituting a vast, dynamic, and polyphonic archive of our actions, choices, interests, habits, opinions, etc." (Bruno, 2012, p.684).

The comprehensive database available on the Internet, in which the behaviors, choices, interests, and opinions of the actors are stored, allows us to say that this is the perfect field for the performance of the roles described by the authors as the main actions that compose the cartography of controversies. There is a great similarity between the aforementioned authors when they describe these roles in general terms, for ex., the capture, analysis, and data visualization described by Marres (2015), the representation and analysis described by Pereira and Boechat (2014), or the exploration and representation described by Venturini $(2010,2012)$. The correlation between these descriptions demonstrates that this method was built on firm foundations and it has been widely adopted in recent years by scholars and institutions. It is worth emphasizing that each of these characteristics pointed out by the authors includes a series of actions that will be described in more detail later in the paper.

Lastly, another similar characteristic in these authors' definitions refers to the brief description of what will be mapped, i.e., the controversy itself. The emphasis given by Marres (2015) on dispute over public issues underscores the feature that makes the controversy "mappable", that is, its publicity made available to a large number of people. On the other hand, Pereira and Boechat (2014) highlighted the importance of the traces that make the discussions on this topic "mappable". Both of them are characteristics of the controversies; however, in order to understand them thoroughly and to identify the most relevant controversy to the work of the cartographer, it is necessary to better conceptualize it, along with the Black-Box concept, the last type of controversy.

\section{From Controversy to Black-Box}

Based on everything that has been discussed so far, the context of richness of the Web, the exponential growth of digital communication, the production of content and provision of information, and the method definitions, it is necessary to have a clear understanding of controversy itself. What characterizes a controversy? Why is the actor-network theory so interested in controversy? What is the correlation between controversy and the black-box?

The definition of controversy is crucial for the understanding of the connection between the Actor-network Theory and the Cartography of Controversies method. A controversy is defined by situations of disagreement, in which human- and non-human agents take a position in the opposite direction, forming different groups, in order to defend a certain position. Highlighting the role of disagreement, Venturini provides a straightforward definition of controversy.

[...] controversies are situations where actors disagree (or better, agree on their disagreement). [...] controversies begin when actors discover that they cannot ignore each other and controversies end when actors manage to work out a solid compromise to live together. Anything between these two extremes can be called a controversy (Venturini, 2010, p.261). 
Between mutual unfamiliarity and alliance there is an ocean of possibilities that can be explored in the development of the controversy since this is when the formation of agreement or opposition groups and the untying connections, that is, the continuous flow of what can be called "social".

The importance of observing a controversy can be confirmed based precisely on this aspect since it is understood as a situation, a phenomenon in which the "social" can be observed in its most dynamic form, where associations are still being formed, i.e., they are not yet established. Thus, "controversy is the ideal moment to reveal the movement of agency, the mediation and translations among actants, the establishment of intermediaries, the relations of force, the conflicts before stabilizing as black boxes" (Lemos, 2013, p.106). It shows itself as the opportune moment where the "social" can be seen as the metaphor of Venturini's magmatic flow in its various states, from liquid to solid: "at the margins of the flow, the lava cools down and crystallizes, some other solid rock touched by the heat of the flow melts and becomes part of the stream" (Venturini, 2010, p.264).

Thus, the interest of the Actor-network theory in mapping controversies becomes clear since they are characterized as the opportune moment to analyze the sociotechnical networks in motion, identifying the actants and their articulations, as pointed out by Pedro (2008) points when describing the network itself.

It is a highly unstable and dynamic configuration with intense exchanges between the various points, connections, and actors. There are, in this composition, common goals and objectives, around which the connections are established. The sociopolitical component inherent in these networks implies possibilities of tension and conflict so that building a consensus - the transformation of the multiple into One - becomes a highly complex process (Pedro, 2008, p.4).

This complex consensus building process is the major characteristic the dynamics of the controversy, which must be carefully mapped by scholars so that every discourse and voice is inscribed, ensuring that their analysis is thorough including all main points of view of the phenomenon chosen.

When carrying out studies on this method, the Cartography of Controversies interest in the discourses of the actants becomes clear, and these discourses are one of their main sources of information in research. Latour (2012) argues that the actor-network theory itself has used elements of narrative and semiotic theories to analyze the relationship between the actant and its action, often established thorough a discourse.

This interest of research in the actants' arguments and statements is due to the fact they reveal social processes, the actions carried out, the opinions, and the roles assumed before the controversy since every controversy functions as a hybrid forum, a space of conflict and negotiation among actors (Venturini, 2010). Accordingly, scholars are especially interested in this material, as pointed out by Pereira and Boechat (2014, p. 559).

In practice, the scholar using ANT starts mapping in order to document in a non-hierarchical way all opinions about a subject, giving each opinion a value within the network, according to their connection patterns that are unstable and modifying references. [...]. The efforts are concentrated on keeping a record of the communications between the actants without filtering them, by describing them without indoctrinating.

These are the guidelines to be followed when using the method to collect information for mapping the controversies, in which valuing the opinions in the network, keeping records, and making descriptions are the major elements of data collection.

Another concept related to controversy that deserves a more detailed explanation is the Black Box. The black box is the final stage of a controversy, when there are no more disputes, and the disagreements are replaced with agreements and a consensus is reached. According to Latour (1987, p.2), "the word black-box is used by cyberneticians whenever a piece of machinery or a set of commands is too complex. In its place they draw a little box about which they need to know nothing but its input and output". On the other hand, Pedro (2008), revisits the discussing about its meaning by introducing the term gray-box as another stage in the development of the controversy: 'gray-boxes', i.e., a research issue that still raises controversies, and questions, and which has not yet become a "black-box". 
Therefore, it is clear that a black-box is an already resolved or ended controversy, but which can be aroused again depending on new questionings and new social processes.

\section{Stages or procedures of the cartography of controversies}

Since the cartography of controversies is a fairly new research method in the country, it is still necessary to use several previous studies to help understanding it in all its complexity because the publications in Portuguese are still spread out. There are some Brazilian studies available using this method (Faria, 2014; Faria; Coutinho, 2015; Guesser, 2005; Pinto; Domenico, 2014; Praude, 2015; Stangl, 2015), but they all provide a brief description, hampering the understanding of the stages and processes of cartography.

Latour (2000) describes the stages, procedures, and precautions required in the use of the method, giving details of the process of following the actors and describing the controversies, suggesting some initial steps:

1) Identify an input - You have to find a way to "enter into the network", access it, and somehow participate in its dynamic.

2) Identify spokespersons - Since multiple human- and non-human actants participate in the network, it is necessary to identify those who "speak on behalf of the network", and summarize the opinion of other actants. It is worth noting that in this process, one must not try to seek the discordant voices, that is, the recalcitrance that is also present in the network.

3) Access the inscription devices, that is, everything that allows a visual display of any kind in texts and documents, and which makes it possible to "objectify" the network.

4) Map the network relationships - Outline the relationships established between the several different actors and nodes that make up the network. It involves the multiple translations produced by the actors, emphasizing their connections, in particular the synergy or cooperation effects in the network; The effects of linking or network repercussion; the crystallization or limitations of the network.

With these four steps, Latour, establishes the beginning of the complex task of mapping controversies, addressing its main precautions. However, the scholar cannot be fooled by the apparent simplicity of these steps because in each one there are minutiae of the Theory Actor-Network that will guide the entire mapping process. The first step includes the need to access the dynamics of the controversy, in which the scholar becomes part of it in order to approach or come close to the actants and visualize the different points of view that make up the controversy.

When getting close to the actants, Latour argues that it is necessary to identify the spokespersons or those who have greater power of influence in the network, bearing in mind the principle of symmetry, in which human actants, at first, are not different from the non-human agents. The access to the documents produced during the controversy follows the identification of the actants since these documents include the actions, discourses, and roles of each actant, making it possible to observe the movements of tying and untying connections of the sociotechnical network. These movements will become clearer after the fourth step, with the mapping of the network connections, allowing a deep analysis of these relationships.

These definitions of Latour provide the basis for the Cartography of Controversies, but in order for it to consolidate as a solid method of research, it is necessary to specify in more detail its tools and recommendations that will guide scholars during the research process. Therefore, Venturini $(2010,2012)$, who also participates in the Latour's MACOSPOL project, has carried out several studies to explain and disseminate the Cartography of Controversies as a method that includes well-established tools. Based on the two main articles of the author, whose objective is to define and explain the main procedures of this method, two major stages of Cartography were 
identified: observing and representing a controversy. Both were explained in detail by the author in some steps and recommendations, as shown in the Chart 1.

It is worth highlighting that Venturini does not introduce these steps, or components of the method, as hierarchically organized steps since many of those actions must occur simultaneously to be able to follow the development of the controversy. There is, indeed, a certain temporal alignment of these actions since one must observe before representing a controversy.

Before discussing these steps and performing the actions of this method, it is important to be fully aware of the seven recommendations proposed by Venturini. They will guide the employment of the method to include the complexity of a controversy. Each recommendation will be adopted in one or more tools that are used during the mapping, and they can also be used as a checklist at the end of the mapping being carried out to ensure a more a comprehensive description of the phenomenon.

The first task proposed by Venturini is the need to observe the controversy to identify its characteristics and verify its validity as an object of research. Therefore, it is necessary cautious when first analyzing its four main characteristics: dynamics, temporality, boundaries, and easy access to necessary data.

Chart 1. Summary of the steps and recommendations of cartography of controversies.

\begin{tabular}{|c|c|c|}
\hline \multirow[t]{8}{*}{ Observing the controversy (Venturini, 2010) } & \multirow[t]{4}{*}{ Choosing a controversy } & Avoid cold controversies \\
\hline & & Avoid past controversies \\
\hline & & Avoid boundless controversies \\
\hline & & Avoid underground controversies \\
\hline & \multirow[t]{4}{*}{ Apply the 5 observation lenses } & From statements to literatures \\
\hline & & From actors to networks \\
\hline & & From networks to cosmoses \\
\hline & & From cosmoses to cosmopolitics \\
\hline \multirow[t]{9}{*}{ Representing the controversy (Venturini, 2012) } & \multirow[t]{9}{*}{ The 9 layers of a controversy website } & Glossary of non-controversial elements \\
\hline & & Documentation repository \\
\hline & & Analysis of scientific literature \\
\hline & & Review of media and public opinions \\
\hline & & $\begin{array}{l}\text { Tree of disagreement (Mapping the opposing } \\
\text { positions or actions of disagreements) }\end{array}$ \\
\hline & & Scale of controversies (boundaries) \\
\hline & & Diagram of actors-networks \\
\hline & & Chronology of dispute \\
\hline & & Table of cosmos \\
\hline \multirow[t]{7}{*}{ The 7 recommendations (Venturini 2012) } & \multicolumn{2}{|c|}{ you shall listen to actors' voices more than to your own presumptions } \\
\hline & \multicolumn{2}{|c|}{ you shall observe from as many viewpoints as possible } \\
\hline & \multicolumn{2}{|c|}{ you shall not restrain your observation to any single theory or methodology } \\
\hline & \multicolumn{2}{|c|}{ you shall adjust your descriptions and observations recursively } \\
\hline & \multicolumn{2}{|l|}{ you shall simplify complexity respectfully } \\
\hline & \multicolumn{2}{|c|}{ you shall attribute to each actor a visibility proportional to its weight } \\
\hline & \multicolumn{2}{|c|}{ you shall provide descriptions that are adapted, redundant and flexible } \\
\hline
\end{tabular}


In order for the analyzed controversy to show the social dynamics as expected by the scholar, it is necessary to verify whether it is a cold or a hot controversy. This indicates the presence of movement, discussions, and translations that can change the controversy. If there is no debate, or if the debate is moving towards a consensus, then controversy is no longer a good controversy to be analyzed since its description may become partial because there are no more conflicts. According to Venturini (2010, p.264), "good controversies are always "hot": they may involve a limited number of actors, but there has to be some action going on".

Another important factor is the temporality of a controversy, i.e., whether it is a present or past controversy, which directly influences its "temperature" and the ease access to the data. Past issues may have been forgotten or unresolved, or they may have had an imposed solution, which implies complications in data search and analysis. However, according to Venturini (2010), past controversies can be investigated only if observation can be moved back to the moment when the controversy was being played out. This process is facilitated by the increase in the use of digital media since controversies that occur in these media leave digital traces (Bruno, 2012).

The last two characteristics of a controversy are directly related to the amount of data available and the level of effort required by the scholar to analyze it. By avoiding boundless controversies, the scholar can make sure that he or she will be able to carry out a very comprehensive study. To recognize that every controversy is complex is the first step in avoiding this issue since it will be possible to recognize that each actant involved is a singular actor and also a network. When mapping a controversy, as it progresses, it reveals a series of new interconnected actions, new discourses, and new actants. Thus, if the scholar choses a huge debate or controversy, he/she will not be able to map it (due to the lack of resources) or the mapping will be superficial. On the other hand, the ease access to data is essential to ensure that there is enough material for analysis because without access to documents, discourses, and controversy inscription devices there is no analysis.

After the controversy is chosen, scholars can start the observation procedure using the five observation lenses. These lenses help scholars observe the controversy from different perspectives (Venturini, 2010) multiplying interferences and ensuring that several voices are heard during the description of the controversy. These lenses are directly associated with the inscription devices, i.e., the documents produced during the development of the controversy by its different actants.

Statements and the specialized literature are included in the first two lenses to be used by the scholar because they are the gateway to the controversy. Statements are indeed the diverse opinions of the actants related to the central issue in the controversy. Nowadays, the digital environment is the most common way used to find the opinions and statements of actants since it allows people to interact, disseminate, and reconstruct contents in different tools. An opinion about a controversial topic can generate a great deal amount of replies and discussions due to the ease in the use of digital media. Venturini (2010) emphasizes the need for the scholar to identify the full extent of the opinions involved in the disputes and recognize the relationships between the statements put out as essential for this action.

When mapping the opinions involved in the disputes, the specialized literature appears as the second lens that should be used in the description of the controversy. Venturini $(2010$, p.266) argues that the "The first task of social cartography is to map this web of references, revealing how dispersed discourses are woven into articulated literatures", i.e., how the topics debated by the actants are addressed in academic journals or the specialized press media. According to this author, the third observation lens refers to a text or any other document that can be understood for analysis as an actant, something that matters to the network. Venturini (2010, p.266) added:"an actor is anything doing something. [...] whenever you wonder if something is acting in a controversy, just ask yourself if its presence or absence does make a difference". Thus, if a particular story in the media or a specific document proved to be important to the network, and if the absence of this material would affect the network design as it was identified, then such document is also an actant, an actor-network, since it mediated transformations in the sociotechnical network. 
Instead of seeing isolated actants, the cartography of controversies must focus on their connections and networks, by understanding them as actors-networks that are are components of networks. Accordingly, in order to use the fourth lens, one must focus on the constant flow of tying and untying connections between these actants, building up the sociotechnical network involved in the controversy. This fourth lens provokes the scholar to see the panorama where the controversy unfolds, mapping people, institutions, objects, documents, discourses, information, and everything that is relevant to form the network.

The fifth lens refers to the identification of the influence of ideologies in the networks, which, based on the observation of the actants'actions and the analysis of their opinions, aims to find out what causes them to act. What can be observed during a dispute is that there are always two sides involved, i.e., two ideologies that try to stabilize the network searching for harmony and consensus. The cartography of controversies calls these ideologies cosmos, aiming to analyze the effect of these cosmos on collective life. In the words of Venturini (2010, p.267), "observation cannot be limited to statements, actions and relations, but has to extend to the meaning that actors attribute to them".

After choosing the controversy and beginning its observation through the five lenses, the cartographer will have enough information to identify the cosmos involved in the debate, identifying the formation of groups and opposition groups that are aligned between agreements and disagreements on certain matters. In addition to the formation of groups, the scholar should begin the processes of representation of this controversy, actions whose purpose is to describe the controversy in all its complexity using various tools. At this point, it is worth mentioning what Venturini had said about the time between the processes of observation and representation of the controversy.

Social cartographers should work out their observations and descriptions at once. Right from the beginning of their campaigns, they will deal with maps. At first, such maps will be rough and incoherent. Yet, these initial and tentative sketches will support observation and facilitate their amending (Venturini, 2012, p.2).

As the cartographer begins to observe the controversy, it is necessary to outline the tying and untying connections, describing them in the form of text and image so that, in the end, there is a timeline diagram of the process. This is because the scholar must know that the map will change with the observation of the controversy, by translating its stages and chronology, the actants and their relations in the sociotechnical network, the tying and untying processes, and the cosmoses and their influence on the development of the controversy.

According to Venturini (2012), the best way to represent this dynamic and complex process of the development of the controversy is the creation of a controversy- website, a place where all information produced by the research can be published, preferably a more interactive interface. This is due to the nature of the data produced during the observation of the phenomenon and the need to represent it in different forms, such as in its chronology or timeline, network diagrams, tables, and other images that contain a great deal of information.

The ability of the web to change between the different levels of information is the crucial factor for his suggestion. Venturini $(2012$, p.8) stated that "digital mediation fills the observation gap between macro-structures and microinteractions as it provides means to move from one to the other". The change between the micro and the macro is fundamental to the cartography of controversies since it materializes the figure of the actor-network, which, if viewed from a distance is a singular point, the actor, but if viewed up-close it opens up as in a new network with several nodes. This is the reason why the digital language contributes so much to studies using this method as it allows exploring the various zoom levels of information about the controversies, by focusing on a specific actant or by analyzing the movement of the cosmoses during the controversy.

In order to make this path clearer, Venturini introduced 9 layers of this web-controversy-website. Each layer is an important tool to unveil the controversy: Glossary of non-controversial elements; Documentation repository; Analysis of scientific literature; Review of media and public opinions; Tree of disagreement (Mapping the opposing 
positions or actions of disagreements). The scale of controversies (boundaries); Diagram of actors-networks; Chronology of dispute; Table of cosmos.

The glossary of non-controversial elements is the first tool provided by the cartography of controversies, in which the scholar should identify common terms, and concepts in the controversy and describe them so that they can be understood by a non-specialist reader. The terms in this glossary can be specialized jargons, technical terminology, and more complex concepts that can be easily explained using the multimedia potential of the Web.

Documentation repository is the complete documentation gathered and produced by the research, i.e., it refers to where, in this controversy-website, users can find all the steps taken by the scholar during the mapping, including a video, audio-recorded or transcribed interviews, photos, and other types of documents. Venturini (2012) highlights that in a hypertextual environment the bibliographic references can provide direct linkage, facilitating users'access to original sources. This repository has an important function to allow the possibility of reusing research data at any time, either to confirm results or to carry out further analyses.

The third layer of this controversy-website is the analysis of scientific literature, in which, in addition to searching information on the topic debated in the controversy, the scholar has a special interest in obtaining an overall view of scientific publications, revealing opposite opinions and collaborations among scientists. Thus, this shows that when analyzing any public controversy one must be aware of what happens in the scientific field, trying to identify points of convergence in scientific debates or how they influence public debates. These points of convergence will be better explored by identifying collaborative networks, formation of alliances and opposition forces, forming clusters around institutions or positions, and identifying actants who have a strong influence on the controversy, such as certain scientists or journals and articles. It is worth mentioning the presence of elements of another commonly used research method, Social Network Analysis, which are present with some metrics and concepts such as clusters, network diagrams, or collaboration graphs, reinforcing the idea that the cartography of controversies in is indeed open to other methods.

Similarly to the analysis of specialized literature, the review of contents and opinions published by the mass media, whose objective is to map what has been discussed about the central subject of the controversy in journalism websites, digital magazines and journals, social media, blogs, and any other web page containing public opinion data. This layer of the controversy-website highlights once more the dialogue with another theory, the Graph Theory and its analysis tools, since with the expansion of the digital field, opinions, disputes, and discussions can now be traced becoming important for the formation of this network of discourses on the web.

According to Venturini (2012), the tree of disagreements is the process of mapping the relationship between disagreements, tracing how the arguments are connected and structured in discourses, and how different discourses are interconnected. To accomplish this task, the author proposes the use of diagrams of hierarchical trees to represent these relationships since they reveal "how the tiniest disagreement between actors is often linked to the broadest opposition in social networks (and vice versa)" (Venturini, 2012, p.15).

The sixth layer of the controversy-website aims to demonstrate the boundaries of the analyzed controversy. The scale of controversies shows the sub-controversies selected by the scholar and their relationship with other controversies. This reinforces the idea that no dispute is isolated; they are always linked to major and minor disputes, composing, perhaps, a super-controversy. In order to make it more clear, one can situate the controversy of the reorganization process in the São Paulo schools in the scale of controversies, which may be related to the supercontroversy in the political dispute scenario in the country between the left and right (a very simplified illustration), or more recently, the clear link with the protests against bus fare increases in the same state. This scale enables the scholar to identify the degree of "generality-specificity" of the controversy, revealing the influence of disputes that take place above or below such dispute (Venturini, 2012). 
To deal with the difficult task of illustrating an actor-network, which is both singular and plural, the diagram of actors-networks was created to show the dynamism of tying and untying connections between these actors during the development of the controversy. Venturini (2012) pointed out the possibility of using digital tools to develop animations that depict this magmatic flow of social phenomena. However, it can be also illustrated using static images. Recent studies have proposed actant diagrams at each extract of the controversy, i.e., each new stage of development. At the end, this will enable the overlaying of the different layers of the diagram demonstrating how an actant that is present in the first image decomposes into a network in the last layer. The diagram of actors-networks allows mapping beyond this dynamics of each actant, identifying which the roles played in the analyzed network by human- and non-human agents, their importance, and their relationships with other actors.

The starting point of the cartography of controversies is probably the design of the chronology of the dispute, that is, the main moments during the development of the controversy. Obviously, the development of controversies is not always continuous and linear; in the words of Venturini (2012, p.17), "sometimes controversies remain dormant for years or decades and then burst in a sudden cascade of disputes". This is the challenge of tracing the timeline of disputes in the controversies, indicating the need to start this process in the beginning of cartography, adding events over time. Today, it is possible to rely on digital tools that create navigable timelines, making it possible to zoom in to examine a specific event or get an overall view including multimedia contents and hyperlinks.

The ninth and last layer is the table of cosmos, whose objective is to represent all ideologies involved in the controversy, showing where there is divergence and convergence between them. This table highlights the influence of these cosmoses on the development of the controversy, demonstrating that the disputes are composed of several different points of view showing the different types of actants that share a certain cosmos. Mapping ideologies is fundamental to understand the behavior of the actants since their actions are motivated and guided by ideologies.

The aforementioned discussion about these 9 layers or 9 tools to map controversies shows that each one represents either a characteristic of the dispute or an important element that has a direct influence on the development of the controversy. It should be emphasized that these steps proposed by the authors do not include all of the situations involved in the mapping of actions provided by the ANT and the Cartography of Controversies. This is due to the endless diversity of phenomena that can be the objects of research. These steps can be understood as the milestones guiding the analyses carried out.

Therefore, it can be said that when used in conjunction with other methods and theories, this set of tools of the Cartography of controversies allows a comprehensive analysis of the development of controversies, identifying the role of the actants, the way they share information and establish relationships in the network, how their influences and opinions change during the development of the controversy, and the type of elements that influence the whole process (ideologies, external opinions, and specialized literature). These are some examples of the issues that can be explored in the Information Science field using this method.

\section{Information Science as a field of sociotechnical studies}

Understanding Information Science as a heterogeneous field of study due to its interdisciplinary relationships is the first step to visualize the dialogues between the Actor-network Theory and the possibilities of using the Cartography of controversies approach in this field. The relationships between technologies and social and cognitive processes in Information Science have been commonly established since the beginning of its development as a scientific field, and this fact is related to the difficulty in precisely defining its object of research, information. 
The relationship between human- and non-human elements is often present in the attempts to define information as a concept and determine its effects on the most diverse contexts analyzed by Information Science. There are human- and non-human agents in the sociotechnical networks formed within the scope of IS. They are present in the focus on the descriptions of documents and cognitive processes used to interpret information, as well as in the development of complex computer systems that can help organizing, collecting, interpreting, storing, retrieving, disseminating, and transforming information.

To illustrate this initial interaction between the actor-network theory and information science, we can refer to Capurro and Hjorland (2003, p.3), who stated that "the most important thing in IS (as in information policy) is to consider information as a constitutive force in society and, thus, recognize the teleological nature of information systems and services". Therefore, it becomes clear how the Actor-network Theory, whose focus is to analyze the tying connections that form collectivities, can contribute to the studies in the IS field, trying to answer some of the following questions: how is information produced and shared? What is the role of information in the formation of a sociotechnical network? What is the role of information systems and services as actants in an information-sharing network? These and other questions can be explored using the cartography of controversies method to describe the dynamics of these processes and the performance of each agent along their path.

\section{Importance of cartography of controversies for IS}

By emphasizing that information is formed by sociocultural and scientific processes, Capurro and Hjorland (2003) shows why the Cartography of Controversy is considered as an interesting method for Information Science. By investigating these sociocultural processes and revealing the social dynamics of establishing links in a controversy, or a specific situation or context, this method shares these authors' concept of information, which is "Information is anything that is of importance in answering a question" (Capurro; Hjorland, 2003, p.25).

This premise shows that information can only be considered as such if it makes sense or if involves a meaning creation process, which is heavily influenced by the context in which the action occurs. This enables us to identify an interaction with ANT and its concepts, by perceiving the meaning creation process as similar to the translation process, proposed by Latour (2012) and Law (1992) since an information is only considered as such when it affects the formulation of answers to a question raised, according to Capurro and Hjorland, i.e., when it brings about a transformation, an effect.

It is important to emphasize that the same information can have different interpretations, depending on the context in which it is inserted. Therefore, it is necessary to recognize that a document or a representation of an object can contain different information and can be understood in very different ways, depending on the actors involved, the environment in which it is inserted, and the conditions under which these relations are established. When studying information, Information Science is thus presented with the challenge to consider users as "individuals in concrete situations within social organizations and domains of knowledge" (Capurro; Hjorland, 2003, p.28). Such challenge can be explored using the Cartography of Controversies (CC) because in retracing the steps taken by the actants, the CC will identify the contexts and situations involved in the information flow in order to identify what is information and what is not, i.e., identify what actually caused changes in the network and what did not.

In the beginning of the cartography, the scholar will notice the importance given to the inscriptions, or, using terms that are commonly used in information science, the stored information, and the documents, since these elements are materialized representations of the actions performed by the actants. The access to the documents produced during the controversy make it possible to retrace the steps of the actants in the network, building up the complex network of sociotechnical relations (Latour, 2012; Praude, 2015). 
This interest in the documentation concerning to the controversy leads to another similarity among the ANT and the cartography of controversies and IS studies, the Venturini's recommendation on the use of other methods in conjunction with CC, mentioning the use of Scientometrics as an important tool for analyzing research.

Scientometrics can reveal the networks of scientific collaboration through the analysis of co-authorship, the relative authority actors (scientists, research centers, journals...) through citation analysis, and the diffusion of ideas through lexicographic analysis. The results of these analyses may be displayed as indicators or as connection graphs. This second method is to be preferred as it allows revealing the opposition and alliances in the scientific community, as well as the existence of disciplinary or institutional clusters (Venturini, 2012, p.14).

The interest of this author in Scientometrics is due to the central focus given by of the Actor-NetworkTheory and by the Cartography of Controversies to topics and issues related to the techno-scientific spheres, which also point to other commonly used methods in IS, such as Bibliometry.

Since the cartography of controversies investigates, among other things, the effects of a document on an action network it provides a comprehensive description of its characteristics. However, its interest goes beyond this description; it seeks to identify the connections established through the document, which is understood as an actant. This demonstrates how the cartography of controversies can contribute to information science to carry out research aiming to analyze the object of study in a complex way and the processes and transformations caused by the information, instead of concentrating only on the description of its types of inscription, as discussed by Capurro and Hjorland (2003, p.29):"It is relatively easy to count the number of words in a document or to describe it in other ways. It is much more difficult to try to figure out for whom that document is of importance, and what important questions are, that the document can answer".

This issue argued by theses authors highlights the challenge faced by Information Science to expand the concept of information as a "thing" (bits, documents, or any other forms of inscription) and understand it in all its subjectivity, i.e., as a sign, something to be interpreted. This shift in perspective to an interpretive conception is essential because it allows recognizing the information processing mechanisms, or the mechanisms that account for information discrimination, interpretation, or selection "What distinguishes different theories of information is, thus, not so much the concept of information itself. It is, to a much higher degree, the nature of the 'release mechanism' (or 'information processing mechanisms'), the selectors or interpreters" (Capurro; Hjorland, 2003, p.19).

The Cartography of Controversies approach itself implies a differentiated perspective of information, understanding it in the complexity of interpretive processes, making the scholar see the document not as an information itself, but rather seek to identify the effects on the network of information using the selection and interpretation processes. Therefore, this method can help Information Science in the analysis of the release mechanisms, the selectors or interpreters, identifying its role in an information sharing sociotechnical network.

Since, "building networks is basically an interpretation process" (Capurro; Hjorland, 2003, p.29), and interpretation is an essential process for understanding the information, the interaction between the Actor-Network Theory and the Cartography controversies method and their possible contributions to the studies in Information Science field becomes clear. The rapid technological advance cannot guide the scholar only to concentrate on the objective elements, overlooking important phenomena that directly influence the information sharing and the tying and untying connections that constitute the "social".

\section{Conclusion}

The objective of this study was to introduce the Actor-Network Theory and the Cartography of Controversies method for scholars working in the Information Science field, highlighting their similarities and their potential. 
Analyzing the first concepts of ANT, it can be seen that there is a close correlation with studies in the IS field; perhaps because both involve the studies in the Science, Technology, and Society (STS) field.

Both in ANT and IS, the relationship between human- and non-human elements deserves closer attention from the scholar since "agency" can be attributed to these elements, that is, they can perform actions. In Information Science, the examples of information retrieval systems (or the computer itself), which manipulate data to perform more complex actions, are clear. Accordingly, a contribution of the ANT is the proposal of analyzing the function role of these elements within an intricate network, trying to understand their influence on the establishment the network connections.

In this movement characterized by the connection process, Law (1992) and Latour (2012) introduced important concepts such as mediation, translation, and inscription, which are closely related to the concepts of document, information interpretation, and release mechanisms, as pointed out by Capurro and Hjorland (2003). Additionally, both Information Science research and research using the Actor-Network Theory and the Cartography of Controversies are based on different network conceptions but with some similarities.

The objective in describing the cartography of controversies and its stages and tools for observation and representation was to demonstrate how the controversy can be seen as an opportunity to study contextualized information. The present study can be used to identify the effects of information on the interpretation processes executed by the actants and the effects of their contribution to the formation of networks.

Therefore, this study aimed at presenting the initial steps for the dissemination of the Actor-Network Theory and the Cartography of controversies method in the Information Science field, understanding that their contributions can be very interesting since they provide an interdisciplinary view by relating the purpose of analyzing the ties of human- and non-human elements to the composition of the "social".

\section{Contributors}

All authors contributed to the conception and design of the study, data analysis and final editing.

\section{References}

Bruno, F. Rastros digitais sob a perspectiva da teoria ator-rede. Revista Famecos, v. 19, n. 3, p. 681-704, 2012. Disponível em: <http://revistaseletronicas.pucrs.br/ojs/index.php/revista famecos/ article/view/12893 >. Acesso em: 5 dez. 2015.

Capurro, R.; Hjørland, B. The concept of information. Annual Review of Information Science and Technology, v. 37, n. 1, p. 343-411, 2003. Available from: <http://www.capurro.de/ infoconcept.html >. Cited: July 13, 2017.

Faria, E. S. Cartografia de controvérsias: conexões entre o conhecimento científico e a disputa sobre a instalação do projeto apolo na Serra do Gandarela. 2014. 190 f. Dissertação (Mestrado em Educação) - Faculdade de Educação, Universidade Federal de Minas Gerais, Belo Horizonte, 2014. Disponível em: <http://hdl.handle.net/1843/BUBD-9Q7EQ7>. Acesso em: 15 dez. 2015.

Faria, E. S.; Coutinho, F. A. Educação científica em ação: a cartografia de controvérsias como prática de cidadania técnico-científica. Cadernos de Pesquisa, v. 22, n. 3, 2015. Disponível em: <https://www.academia.edu/20003608/ Educa\%C3\%A7\%C3\%A3o_Cient\%C3\%Adfica_em_A\%C3\%
A7\%C3\%A30_A_cartografia_de_controv\%C3\%A9rsias_ como_pr\%C3\%A1tica_de_cidadania_t\%C3\%A9cnicocient\%C3\%Adfica>. Acesso em: 5 dez. 2015.

Guesser. A. H. Software livre e controvérsias tecnocientíficas: uma análise sociotécnica no Brasil e em Portugal. 2005. 183 f. Dissertação (Mestrado em Sociologia Política) - Faculdade de Sociologia, Universidade Federal de Santa Catarina, Florianópolis, 2015. Disponível em: <http://repositorio.ufsc. br/handle/123456789/101621 >. Acesso em: 15 dez. 2015.

Latour, B. Science in action: how to follow scientists and engineers through society. Cambridge: Harvard University Press, 1987.

Latour, B. Ciência em ação: como seguir cientistas e engenheiros sociedade afora. São Paulo: Unesp, 2000.

Latour, B. Reassembling the social: An introduction to actornetwork-theory. Oxford: Oxford University Press, 2005.

Latour, B. Reagregando o social: uma introdução à teoria do Ator-Rede. Salvador: Edufba, 2012.

.


Law, J. Notes on the theory of the actor-network: Ordering, strategy, and heterogeneity. Systemic Practice and Action Research, v. 5, n. 4, p. 379-393, 1992. Available from: <http:// www.heterogeneities.net/publications/Law1992NotesOn TheTheoryOfTheActorNetwork.pdf>. Cited: Nov. 20, 2015.

Lemos, A. Espaço, mídia locativa e teoria ator-rede. Galáxia, n. 25, p. 52-65, 2013. Disponível em: <http://revistas.pucsp. br/index.php/galaxia/article/view/13635>. Acesso em: 10 jul. 2015.

Marres, N. Why map issues? On controversy analysis as a digital method. Science, Technology and Human Values, v. 40, n. 5, p. 655-686, 2015. Available from: <http://sth.sagepub.com/ content/early/2015/03/16/0162243915574602.abstract $>$. Cited: Jan. 15, 2016.

Medeiros, J. S. Uma investigação sobre a autoria de dados científicos: Teias de uma rede em construção. 2015. 192 f. Tese (Doutorado em Comunicação e Informação) - Faculdade de Biblioteconomia e Educação, Universidade Federal do Rio Grande do Sul, Porto Alegre, 2015. Disponível em: <http://hdl. handle.net/10183/116504 >. Acesso em: 10 jan. 2016.

Pedro, R. Redes e controvérsias: ferramentas para uma cartografia da dinâmica psicossocial. In: ESOCITE: Jornadas Latino-Americanas de Estudos Sociais das Ciências e das Tecnologias, 7., Rio de Janeiro, 2008. Anais eletrônicos... Rio de Janeiro: UFRJ, 2008. Disponível em: <http://www.necso. ufrj.br/esocite2008/resumos/36356.htm>. Acesso em: 15 jan. 2016.

Pereira, D. C.; Boechat, M. P. Apenas siga as mediações: desafios da cartografia de controvérsias entre a Teoria Ator-rede e as mídias digitais. Revista Contemporânea: Comunicação e Cultura, v. 12, n. 3, p. 556-575, 2014.
Pinheiro, N. A. M.; Silveira, R. M. C. F.; Bazzo, W. A. Ciência, tecnologia e sociedade: a relevância do enfoque CTS para o contexto do ensino médio. Revista Ciência e Educação, v. 13, n. 1, p. 71-84, 2007. Disponível em: <http://www.scielo. br/pdf/ciedu/v13n1/v13n1a05.pdf>. Acesso em: 15 jan. 2016.

Pinto, C. C.; De Domenico, S. M. R. Teoria Ator-rede em estudos organizacionais: encontrando caminhos via cartografia de controvérsias. In: Encontro de Estudos Organizacionais da Anpad, 7., Gramado, 2014. Anais eletrônicos... Gramado: Anpad, 2014. Disponível em: <http://www.anpad.org.br/ anpad/ eventos.php?cod_evento $=4 \&$ cod_evento_edicao $=72 \&$ cod_ edicao_subsecao $=1045 \&$ cod_edicao_trabalho $=16857>$. Acesso em: 20 maio 2015

Praude, C. C. Arte computacional e Teoria Ator-rede: Actantes e associações intersubjetivas em cena. 2015. 247 f. Tese (Doutorado em Artes) - Instituto de Artes, Universidade de Brasília, Brasília, 2015. Disponível em: <http://repositorio.unb. br/handle/10482/19018>. Acesso em: 10 jan. 2016.

Stangl, A. Por uma cartografia de controvérsias culturais: o caso dos rolezinhos. In: Encontro de Estudos Multidisciplinares em Cultura, 11., Salvador, 2015. Anais eletrônicos... Salvador: UFBA, 2015. Disponível em: <https://andres tangl.files. wordpress.com/2015/08/artigo-andre-stangl-corrigido.pdf>. Acesso em: 10 jan. 2016.

Venturini, T. Diving in magma: How to explore controversies with actor-network theory. Public Understanding of Science, v. 19, n. 3, p. 258-273, 2010.

Venturini, T. Building on faults: How to represent controversies with digital methods. Public Understanding of Science, v. 21, n. 7, p. 796-812, 2012. Available from: <http://www.medialab. sciences-po.fr/publications/Venturini-Building_on_Faults. pdf >. Cited: July 13, 2017. 